\title{
AN ENGLISH PROFICIENCY STUDY ON STUDENTS OF A DEVELOPING ISLAMIC HIGHER EDUCATION
}

\author{
ABDUR ROFIK \\ Universitas Sains Al-Quran \\ Abdur.rofik32@yahoo.com \\ CHRISTINA CHRISTINA \\ Universitas Sains Al-Quran \\ ATINIA HIDAYAH \\ Universitas Sains Al-Quran
}

DOI : http://dx.doi.org/10.29300/ling.v6i2.3008

Received: April 5th 2020

Accepted: November 3rd 2020

Published: December 3rd 2020

\begin{abstract}
This is a case study that aims at analyzing students' English proficiency as reflected in students' TOEFL-Like scores at Universitas Sains Alqur'an Central Java in Wonosobo, Indonesia particularly years 2017, 2018, and 2019. The study focuses on students' achievement of English proficiency embedded in TOEFL-Like scores which consist of three sections, namely Listening, Structure and Written Expression, and comprehension of Reading. Considering the huge number of the data (2811 participants), to do the research, the data are conducted statistically using the SPSS application. In detail, the data were analyzed using descriptive statistics to find mean (to know students proficiency achievement), minimum, maximum and standard deviation values (to know the variance of students' English proficiency levels). Categorization of the proficiency levels is referred to Common European Framework of Reference for Languages (CEFR) standard. The study revealed that structure and written expression is the most difficult test faced then consecutively reading and listening. Then, the lowest and the highest scores were 217 and 567 with a standard deviation 31, 4. Furthermore, the mean of the total TOEFLLike score achieved was 369,09 . Therefore, the students were mostly categorized as basic users (A2). The study suggests that an appropriate module can be considered to help the students to reach better proficiency, especially in a matter of structure and written expression section.
\end{abstract}

Keywords: TOEFL, Proficiency test, English Proficiency, Higher Education, TOEFL problems

\section{INTRODUCTION}

In the last decade, TOEFL has been increasingly used in educational scope, especially for higher education students as their requirement of graduation. TOEFL is believed being able to be used as a tool of foreign language ability measurement for English as foreign language users. Moreover, the test actually can be used not only for graduation requirements but also for purposing to decide students' placement into ESL class (Baron, 2016). According

How to cite this article: Rofik, A., Christina, C., \& Hidayah, A. (2020). An English proficiency study on students of a developing islamic higher education. Linguists : Journal Of Linguistics and Language Teaching, 6(2), 86-97. doi: http://dx.doi.org/10.29300/ling.v6i2.3008 
to English Testing Service, the test was first developed to examine International students' English proficiency who wanted to study at colleges or universities in Canada.

TOEFL test can be conducted with the internet and paper-based. This study uses a paper-based test. Furthermore, the TOEFL paper-based test can be divided into some kinds, such as TOEFL ITP and TOEFL-Like or Preparation Test. Also, the format of TOEFL paperbased has various types, but in general it consists of three sections. Pyle \& Munos (1991: 3) formed the TOEFL to be listening comprehension, structure and written expression, and vocabulary and reading comprehension. It is similar to Pyle and Munoz, Phillips (2001) divided the TOEFL to be three parts, namely listening, structure and written expression, and reading. TOEFL which is used in UNSIQ is PBT. The TOEFL PBT, administered in a paperand-pencil format, measured test takers' ability to use and understand English in a classroom setting at the college or university level. It accurately measured how well test takers could listen, read and write in English while performing academic tasks (ETS: 2019).

Furthermore, TOEFL-Like Test held in UNSIQ is involved as a norm-referenced test (NRT) as this test, which is used for research importance, captures test-takers' achievement in terms of average and median scores. Moreover, the test scores also perform standard deviation (variance), and percentile rank (Brown, 2003: 7). One of the test purposes is to spread out participants' English language skills (Brown, 1996). Besides, TOEFL as a graduation benchmark policy is perceived as a positive attitude by students $(\mathrm{Wu} \&$ Lee, 2017). Different from the students' perspective, the policy of implementing tests of English proficiency as graduation requirements has no impact on teaching English based on views of teachers, departmental directors, and members of the advisatory committee (Hsu, 2009).

Following English foreign language proficiency (TOEFL) phenomena, the tests widely conducted in Indonesian Universities are still a problem for students. A recent study done by Yuyun, et al (2018) found that in the English proficiency test, from three sections examined, reading comprehension is the most difficult section faced by the students. Similar to this study, students of UNSIQ has some problems to face TOEFL tests. Based on a foreign language perspective, learning English in UNSIQ as an Islamic higher education needs to consider the weaknesses of grammar. Furthermore, Rofik \& Sahid (2019) found that UNSIQ students committed various errors in structuring tenses of English.

Different from Yuyun, Sugeng et. al (2012) discovered that new students' language components of a state university in Yogyakarta were 35,5\% for reading, 31,25\%, for structure and written expression and $27,2 \%$ for listening. Therefore, the data indicated that the most problematic section was listening. 
Understanding some studies above and measuring whether or not TOEFL is considered failing to achieve its goal to enhance students' ability in English proficiency moreover to raise students' career opportunities. It is essential to explore the present study to find the appropriate problems faced by students in higher education. The initial step is to reveal students' proficiency levels, the easiest and the most problematic section of TOEFL, and student's variance language skills. By knowing these essential research objectives, the results of the study enable to propose solution to support educational policy.

\section{METHODS}

\section{Subjects of the Study}

This is a field study conducted in Universitas Sains Alqur'an (UNSIQ) Wonosobo, Indonesia, precisely in the Integrated Service Unit (ISU). The laboratory of ISU is the place in which the data of the study taken. The study is done during 2 months, namely October until November 2019.

This study involved students of UNSIQ who took TOEFL-Like tests during February 2017 until April 2019. The tests were held by the Integrated Services Unit of Language. The number of participants is as presented in table 1.

Table 1. Students in years

\begin{tabular}{cc}
\hline Years & Test Takers \\
\hline 2017 & 1160 \\
2018 & 1265 \\
2019 & 386 \\
\hline Total & 2811 \\
\hline
\end{tabular}

\section{Research Instrument}

The instrument of the study is in the form of columns to input some terms, namely: name of students, students' numbers, date of test registration, and date of test year. Besides those columns, the researchers are also provided with columns for scores of listening, structure and written expression, reading, and total score results.

\section{Data Collecting}

The data are in forms of TOEFL-Like test scores that consist of three test components, i. e; listening, structure and written expression, and reading comprehension. The data also include total scores of those three sections. The data were collected from the 
Integrated Service Unit, the Language Section of UNSIQ. The data were gathered based on the test components.

\section{Data Analysis}

The data analyzed are taken from the first test scores done by the students (before their remedial tests). The test results, which have been converted based on Phillip's (2001) conversion chart, are then analyzed using quantitative methods to find out a descriptive statistics to meet mean, standard deviation, minimum, and maximum. Furthermore, the data are transformed into interval values to get students' category proficiency levels. The values are referred to as following 627-677: 1, 543-626: 2, 460-542: 3, and 337-459: 4. Standard deviation is used to measure homogeneity levels of students' proficiency skills. The minimum is to find the lowest score. The maximum is to get a maximal score. And the percentage is used to find levels of students' proficiency.

The steps to get the results of descriptive statistics data are consulted to Ghozali (2011) with using the SPSS program. The levels of students' achievement then are categorized into some kinds of interpretation which are referred to CEFR as illustrated in table 2. Also, the scores that do not correspond to those categories since they are under the provided minimum achievement will be interpreted as basic users (A1).

Table 2. Categorization of students' Proficiency based on CEFR for languages

\begin{tabular}{lll}
\hline Scores & Category & Interpretation \\
\hline $627-677$ & C1 & Proficient User \\
$543-626$ & B2 & Independent User \\
$460-542$ & B1 & Independent User \\
$337-459$ & A2 & Basic User \\
\hline
\end{tabular}

\section{FINDINGS AND DISCUSSION}

The findings of 2811 students from years 2017 until 2019 are analyzed and described orderly. There are four scores analyzed to know the competency mapping of the test takers. Those are comprehension of listening, structure and writing, reading, and total scores achieved.

\section{Students' Mapping Proficiency}

The results of the analysis in this phase are in forms of descriptive statistics to find mean, range, minimum and maximum values. Data analysis is presented as seen in table 3 . Linguists: Journal of Linguistics and Language Teaching Vol. 6, No. 2, December 2020 
The analysis is done based on each section of TOEFL so that the easiest and the most difficult section based on the students' results can be determined.

\section{Table 3. Listening Proficiency}

Descriptive Statistics

\begin{tabular}{|l|l|l|l|l|l|l|l|l|l|}
\hline & $\mathrm{N}$ & Range & $\begin{array}{l}\text { Minimu } \\
\mathrm{m}\end{array}$ & Maximum & Sum & \multicolumn{2}{|l|}{ Mean } & Std. Deviation & Variance \\
\cline { 2 - 9 } & Statistic & Statistic & Statistic & Statistic & Statistic & Statistic & Std. Error & Statistic & Statistic \\
\hline $\begin{array}{l}\text { Listening } \\
\text { Valid } \\
\text { (listwise) }\end{array}$ & 2811 & 43.00 & 24.00 & 67.00 & $1.13 \mathrm{E} 5$ & 40.0854 & .09570 & 5.07381 & 25.744 \\
2811 & & & & & & & & & \\
\hline
\end{tabular}

To have the description, the mean of listening competency of students is manifested by score 40, 08. In frequency analysis results, the lowest conversion score (24) is achieved by $10(0,4 \%)$ students, and the highest score (67) is found on one $(0,0 \%)$ student. Most of the students (392/14\%) achieved 41 for listening. Based on the analysis results, it can be concluded that students' competency for listening mostly corresponds to A2.

To understand the factors affecting listening results that provide three parts of different section in TOEFL, we first have to know that listening is a very complex process (Burk, 2001). And to find the precise problems, we need to know the item points tested. Listening parts in this term involve a short conversation, a long dialogue, and a long talk. Usually, students start being confused when they do the second section of listening comprehension. This is because one dialogue is used to test some numbers. In this phase, students should pay more concentration, but they often fail to show better performance. Furthermore, the difficulty of listening is faced by undergraduate students, as Sugeng, et. al. finding (2012) revealing that listening is considered the most difficult section tested in TOEFL. 
Descriptive Statistics

\begin{tabular}{|c|c|c|c|c|c|c|c|c|c|}
\hline & $\mathrm{N}$ & Range & $\begin{array}{c}\text { Minimu } \\
\text { m }\end{array}$ & $\begin{array}{c}\text { Maximu } \\
\mathrm{m}\end{array}$ & Sum & \multicolumn{2}{|c|}{ Mean } & Std. Deviation & Variance \\
\hline & Statistic & Statistic & Statistic & Statistic & Statistic & Statistic & Std. Error & Statistic & Statistic \\
\hline $\begin{array}{l}\text { Struc \& } \\
\text { Writt Exp } \\
\text { Valid N } \\
\text { (listwise) }\end{array}$ & $\begin{array}{l}2811 \\
2811\end{array}$ & 29.00 & 20.00 & 49.00 & $9.80 \mathrm{E} 4$ & $\begin{array}{r}34.853 \\
1\end{array}$ & .09014 & 4.77934 & 22.842 \\
\hline
\end{tabular}

Based on the table 4, the mean of structure and written competency is 34,85 . The statistics descriptive of frequency shows that the lowest score is 20 made by 15 students ( 0 , $5 \%)$. The highest is 49 achieved by 2 students $(0,1 \%)$. Most students, 361 test-takers, score 350.

Getting mean 34, 85 reflects that the students should increase their ability. Moreover, UNSIQ requires a 375 score for their undergraduate student graduation. While to get 375 rationally, the scores consist of 37 for listening, 37 for structure and written performance, and 38 for reading. Structure or grammar is used to mean the analysis of the language system (Alderson \& Bachman, 2004), therefore this section is perceived difficult for EFL students.

Furthermore, in deductive language learning, students are asked to memorize, recite particular rules, and examples to achieve a good level of grammar. Consequently, the students should spend their time learning these terms, but the facts reveal that the test takers are dominated by the students who focus on their graduation despite mastering EFL materials. Moreover, the test takers are those who are in the last semester of the study period. Most of them have a limited time to their TOEFL test preparation as they need to prepare their thesis proposal examination. 
Descriptive Statistics

\begin{tabular}{|l|c|r|r|r|r|r|r|r|r|}
\hline & $\mathrm{N}$ & Range & $\mathrm{m}$ & $\mathrm{m}$ & Sum & \multicolumn{2}{|c|}{ Mean } & Std. Deviation & Variance \\
\cline { 2 - 9 } & $\begin{array}{r}\text { Statis } \\
\text { tic }\end{array}$ & Statistic & Statistic & Statistic & Statistic & Statistic & Std. Error & Statistic & Statistic \\
\hline $\begin{array}{l}\text { Reading } \\
\text { Valid N } \\
\text { (listwise) }\end{array}$ & 2811 & 51.00 & 16.00 & 67.00 & $1.01 \mathrm{E} 5$ & 35.7972 & .09001 & 4.77212 & 22.773 \\
\hline
\end{tabular}

Table 5 indicates that the minimum score is 16 , the maximum is 67 , and the mean of reading achievement is 35, 79. From the frequency of descriptive statistics conducted, it uncovers that the lowest grade is made by 2 students $(0,1 \%)$. One student $(0,0 \%)$ achieves the highest one. And most students' scores $(248 / 8,8 \%)$ gather in 38.

As referred to the ETS score description, 38 score corresponds to A2. We know that assessing reading purposes is to know how well the performance of reading predicts how students read in some context (test and real context), (Alderson, 2000). A2 achievement levels reflect that students' reading completion needs to be noticed. To sum up the students' mapping proficiency based on students' achievement from the years 2017 to 2019 is presented as chart 1 below.

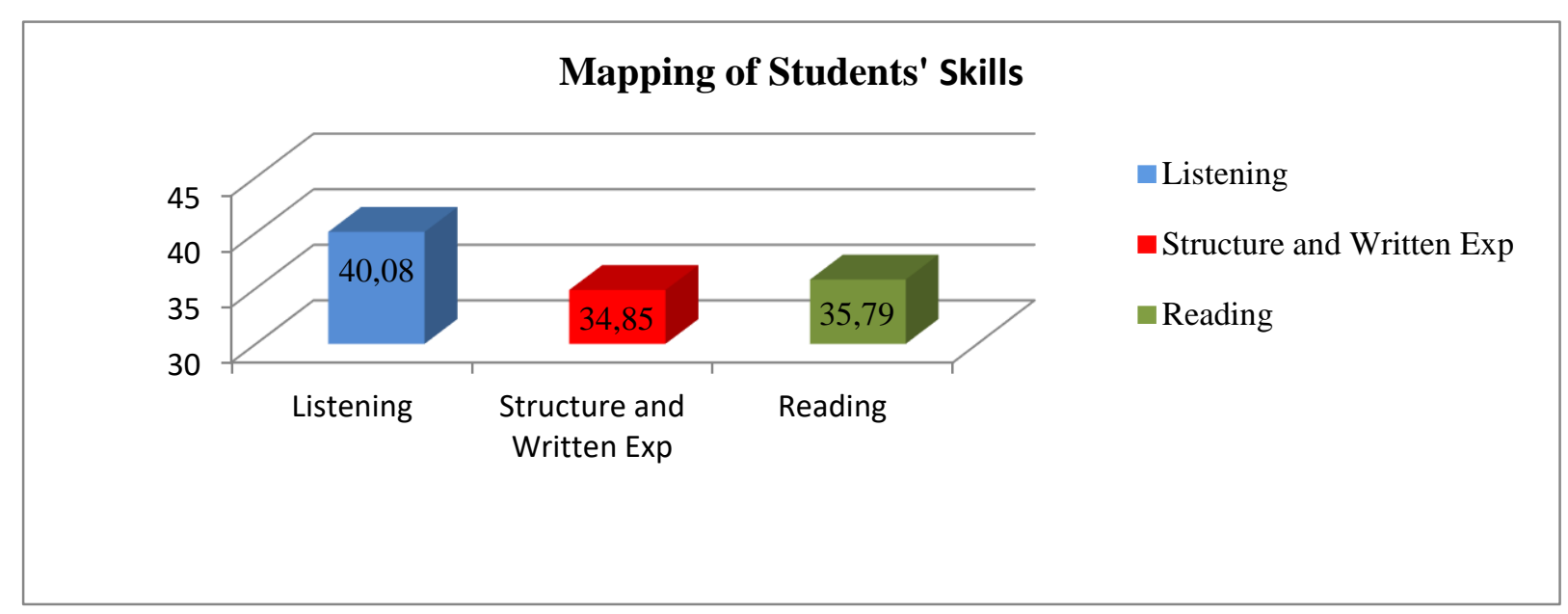

Chart 1. Students' Skills Dissemination

Based on the chart above, it is concluded that the most problematic skill faced by the students is structure and written expression (score: 34, 85). Listening is perceived as the easiest skill tested (score: 40, 08), while reading $(35,79)$ is positioned between two previously mentioned skills. 
Table 6. Total Score of Proficiency

\begin{tabular}{|l|r|r|}
\hline & TOTAL_SCORE & LEVEL_PROFE \\
\hline N Valid & 2811 & 2406 \\
Missing & 0 & 405 \\
Mean & 369.09 & 4.00 \\
Median & 377.00 & 4.00 \\
Mode & 377 & 4 \\
Std. Deviation & 31.438 & 076 \\
Variance & 988.378 & .07 \\
Range & 350 & .006 \\
Minimum & 217 & 2 \\
Maximum & 567 & 2 \\
Sum & 1037524 & 4 \\
& & 9612 \\
\hline
\end{tabular}

TOEFL proficiency levels as presented in Table 6 indicate that mean belongs to 369, 09. The lowest total score is 217 and the highest one is 567 . The range is 350 . The findings reflect that the homogeneity of the students' ability in TOEFL is low. It is also reflected as the homogeneity analysis result which finds a standard deviation 31, 438. From frequency statistics, the data show that the score 217 belongs to 9 students $(0,3 \%)$. The maximum score, 567 , is gotten by one student $(0,0 \%)$. Furthermore, most of the students (396) get 377. The levels of proficiency for the overall skills achieved by the students are illustrated as the chart below.

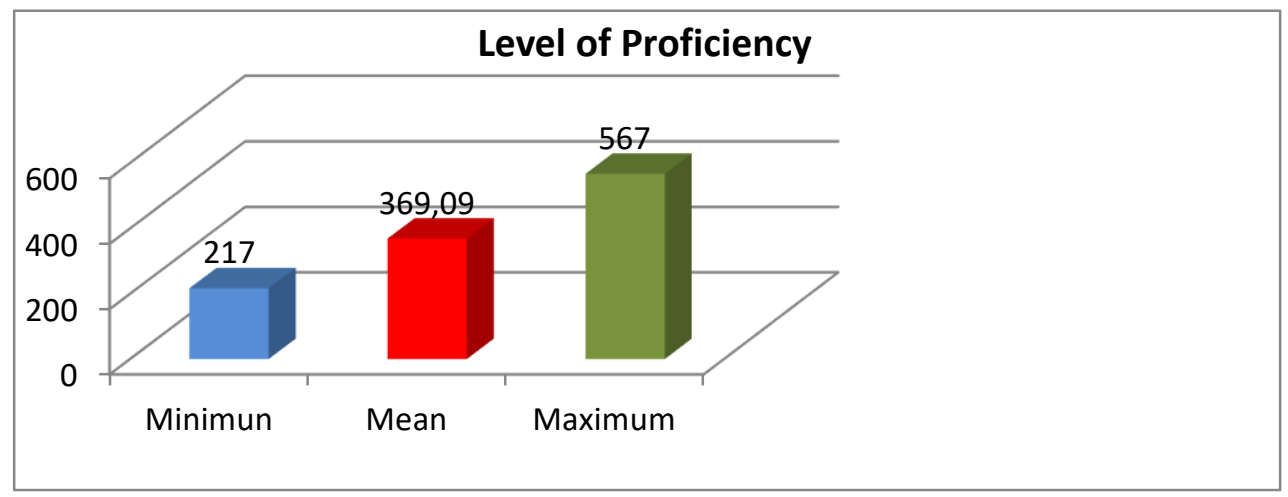

Chart 2. Proficiency Levels

The chart 2 discloses that the students' proficiency range looks varies. The score 217 is the most minimum achievement based on Phillip's conversion (2001). Normally, the students will have a very low opportunity to get these scores. Nevertheless, the marks tend to Linguists: Journal of Linguistics and Language Teaching Vol. 6, No. 2, December 2020 

indicate that some students make fraud during their tests therefore they fail to pass TOEFLLike test score. Following, the scores 369, 09 indicates that students' proficiency levels lie in this point. UNSIQ students' proficiency is almost similar to mean of UNY new students as Sugeng found (2012) that stated that state university students' mean score was 367,218 . The mean is not high. Therefore, the students of UNSIQ need to raise this level. The last, the maximum score is $\mathbf{5 6 7}$. Score 567 is good achievement unfortunately, only one student that get this score.

Table 7. Category of Proficiency

Students' Proficiency Levels

\begin{tabular}{|lr|r|r|r|r|}
\hline & Frequency & Percent & Valid Percent & Cumulative Percent \\
\hline Valid & $543-626$ & 1 & .0 & .0 & .0 \\
& $460-542$ & 10 & .4 & .4 & .5 \\
& $337-459$ & 2395 & 85.2 & 99.5 & 100.0 \\
& Total & 2406 & 85.6 & 100.0 & \\
& 405 & 14.4 & & \\
Missing & System & 2811 & 100.0 & & \\
Total & & & &
\end{tabular}

The table 7 illustrates that proficiency level of independent users (B2) belongs to one student $(0,0 \%), 10$ students $(0,4 \%)$ are independent users (B1), 2395 students $(85,2 \%)$ are categorized as basic users (A2), and 405 students (14, 4\%) as basic users (A1). The 14, $4 \%$ of students reflect that they have a score below 337 as the proficiency minimum standard is seen as "missing" in descriptive statistics analysis results. To make clear, chart 3 illustrates the finding.

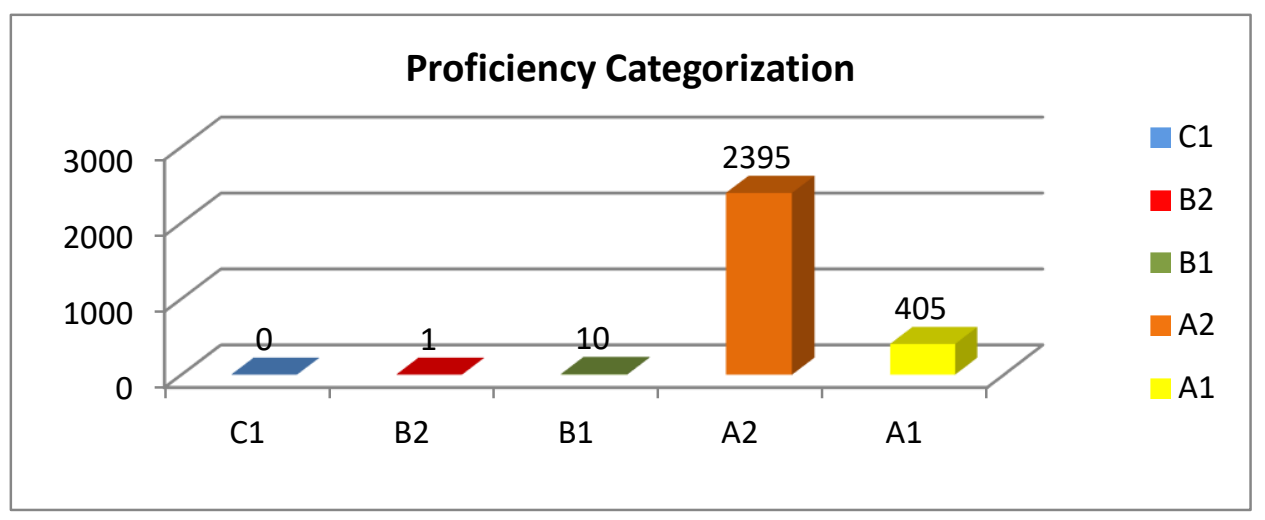

Chart 3. Students' Category

As seen in the chart above, students are gathered in level A2. Level B1 shows a small number of students' achievements. It is different from level A2 which manifests most of students' proficiency achievement. It means that their scores are mostly interpreted from 337 
to 459. As described in the ETS score description, A2 means that students sometimes can understand stated information explicitly in written expression and short conversation that contains simple vocabulary. Furthermore, students are sometimes able to understand main ideas when they are reinforced strongly in certain texts and short oral massages. Moreover, in simple contexts, the students are sometimes capable to select the suitable verb tense and choose appropriate singular and plural types of nouns.

The results depict that students' achievement in A2 illustrates their fewer skills in the language. Some factors may explain the results, e. g; fewer basic English knowledge, motivation, and practice (Mahmud, 2014). Even though students have learned English since their study in university, some facts discover that students who take on the English study program perceive English as a difficult lecture. The phenomena may reflect that they have less practice or motivation to this subject. The evidence is in line with Halim \& Ardiningtyas (2018) revealing that related to TOEFL, students have insufficient English language skills, less motivation and practice.

\section{CONCLUSION}

UNSIQ Students' score means from February 2017 to April 2019 from 2811 participants in the parameter of TOEFL-Like is 369. The score indicates that most of their proficiency levels are categorized as A2/basic users. The point that should be counted is that 405 test-takers get basic users (A1). Moreover, only a student gets the highest one, i. e; 567 and 10 students get a score from 460 to 542 . The lowest one is 217 which is achieved by a student.

Furthermore, structure and written expression is perceived as the most difficult skill $(34,85)$. Besides, listening is manifested as the easiest section tested (40, 08). And reading comprehension is between those two skills $(35,79)$. Students' skills in TOEFL are manifested as high homogenous (SD: 31,438$)$.

The study suggests that the scores indicating students' proficiency can be used to formulate the TOEFL course for new students. Appropriate materials are believed being able to raise students' language competency. The study encourages further research to find particular findings, such as the listening, grammar, and writing problems in TOEFL so that specific modules can be developed. Since good materials will effect to students as Barnes' finding (2016) that stated that source materials influence what the teachers teach and how they teach. Especially for listening materials, relevant listening information significantly influences examinees. Moreover, Freedle \& Kostin, (1996) found that test takers actively try to understand listening materials. Mapping students' proficiency is a further important part to 
be analyzed as Alderman's statement (1981) shared that research based on the study program also needs to be conducted to find the mapping of students' proficiency that indicates readiness for academic study in English. In addition, UNSIQ students need particular consideration in structure and written expression ability. Therefore, a special grammatical material should be addressed to solve this matter.

\section{REFERENCES}

Alderman, D. L. (1981). Language proficiency as a moderator variable in testing academic aptitude. ETS Research Report Series. 1981(2). doi: https://doi.org/10.1002/j.2333-8504.1981.tb01268.x Alderson, J. C. (2000). Assessing reading. Cambridge. Cambridge University Press.

Alderson, J. C., \& Bachman, L. F. (2004). Assessing grammar. Cambridge. Cambridge University Press.

Barnes, M. (2016). The washback of the TOEFL iBT in Vietnam. The Australian Journal of Teacher Education. 41(7). doi: https://doi.org/10.14221/ajte.2016v41n7.10

Baron, P. A. (2016). Setting language proficiency score requirements for English as a second language placement decision in secondary education. ETS Research Report Series. 2016(1). doi: https://doi.org/10.1002/ets2.12102

Brown, H. D. (2003). Language assessment: Principles and classroom practice. Pearson Longman.

Brown, J. D. (1996). Testing in language program. New Jersey. Prantice Hall Regents.

Burk, G. (2001). Assessing listening. Cambridge: Cambridge University Press.

ETS. https://www.ets.org/toefl_itp/research/performance-descriptors/. Accessed on 4 October 2019.

Freedle, R., \& Kostin, I. (1996). The prediction of TOEFL listening comprehension item difficulty for mini talk passages: Implication for construct validity. ETS Research Report Series. 1996(2). doi: https://doi.org/10.1002/j.2333-8504.1996.tb01707.x

Ghozali, I. (2011). Aplikasi analisis multivariate dengan program IBM SPSS 19. [Multivariate analysis application with IBM SPSS 19 program] Semarang: Badan Penerbit Universitas Diponegoro.

Halim, N. \& Ardiningtyas, S. Y. (2018). Difficulties faced by the students in answering the TOEFL test question. ETERNAL: English, Teaching, Learning, and Research Journal. 2(2). Url: http://journal.uin-alauddin.ac.id/index.php/Eternal/article/view/6213

Hsu, H., F. (2009). The impact of implementing English proficiency tests as a graduation requirement at the Taiwanese university of technology. Doctoral Thesis. University of York. Retrieved from: https://core.ac.uk > download > pdf

Mahmud, M. (2014). The EFL students' problems in answering the Test of English as a foreign language (TOEFL): A study in Indonesian context. Theory and Practice in Language Studies. 4(12). pp. 2581-2587. Doi: http://doi.org/10.4304/tpls.4.12.2581-2587

Phillips, D. (2001). Longman complete course for the TOEFL test: Preparation for the computer and paper tests. New York: Addison-Wesley Longman, Inc.

Pyle, M, A., \& Munoz, M, E. (1991). TOEFL preparation guide: Test of English as a foreign language. Singapore: John Wiley \& Sons (SEA) Pte. Ltd.

Rofik, A., \& Sahid. (2019). Structuring tenses of English by Islamic higher education students: A case Study at Universitas Sains Alqur'an. IJEVS: International Journal for Educational and Vocational Studies, 1(1), 25-30. doi: https://doi.org/10.29103/ijevs.v1i1.1391

Sugeng, B,. et al. (2012). Penguasaan bahasa Inggris mahasiswa baru UNY tahun ajaran akademik 2005/2006 - 2009/2010 pada kriteria TOEFL-LIKE. LITERA. 11(2), 189-203. 
Wu, J., \& Lee, M. C. (2017). The relationships between test performance and students' perceptions of learning motivation, test value, and test anxiety in the context of the English benchmark requirement for graduation in Taiwan's universities. Lang Test Asia 7(9). doi: https://doi.org/10.1186/s40468-017-0041-4

Yuyun, I. et al. (2018). A study of English proficiency tests among first-year university students. Journal of Language and Literature. 18(1), 1-8. Url: https://ejournal.usd.ac.id/index.php/JOLL/article/view/1046 